\title{
The Analysis of Problems in Application of International Financial Reporting Standards in Kosovo
}

\author{
Agim Kastrati \\ Universiteti Europian i Tiranës
}

akastrati7@hotmail.com

Abstract

Financial reporting, in terms of the internationalization of business, has a special role because the preparation of the complete and exact information is vital for users of financial statements, to support their decisions. Recent years in many countries there is a tendency towards harmonization of the use of International Financial Reporting Standards (IFRS). In this sense IFRS represent a set of accounting standards that enable the compilation of comprehensive and transparent financial reports. In Kosovo, since 2011, with the Law on financial reporting has become mandatory application of IFRS for all entities. Fulfilling this obligation, except different priorities, often presents numerous difficulties for entities in their practical implementation. The practical application of IFRS for entities presents a problem because of the complexity of these standards and frequent changes made by the makers of these standards. Analysis of the collected data enables the detection of the current state of practical implementation of IFRS and problems during the implementation of accounting standards by entities. Based on data collected from the practical problems of economic units, will made recommendations in order to assist professionals in the accounting field, without damaging the quality of financial information.

Keywords: IFRS, financial reporting, accounting standards

\section{Introduction}

In the globalized capital markets, differences in accounting standards, makes financial statements less understandable and comparable. These differences hamper the ability of efficient capital commitment of investors and creditors.

Application of International Accounting Standards (IAS) assists companies seeking financing, reducing the costs of being in compliance with different accounting standards. In this way it reduces the risk of information for capital providers, as a result of trust in the information of financial statements prepared under International Financial Reporting Standards (IFRS).

In Kosovo since 2011, all large enterprises, small and medium-sized entities, that are limited liability companies, are required to apply full IAS and IFRS to the preparation of financial statements (Law 04 / L -014).

\section{Objectives of the study}

The application of IFRS / IAS, except priorities of the financial reporting, there are some problems in practice, due to the complexity of these standards. Problems also arise because these standards are changed too often as a result of the global needs of modern economy.

In terms of Kosovo's economy, the application of these standards becomes complicated and costly. Lack of professional staff for the application of these standards increases the problems of applying these standards, especially for small and medium entities. This issue becomes problematic because, based on the current law, all entities regardless of their size, are required to apply full IAS and IFRS for the financial reporting. Therefore, the main purpose of this paper is to make evidence of the level of implementation of international financial reporting standards and the problems that arise in practice in relation to these standards. 


\section{Methodology}

In the case of data collection for this research, used is critical incident technique (CIT). CIT is a set of procedures that are characterized by collecting data from direct observations of human behavior.

Where researchers faced weak or no theoretical foundations for the phenomenon they studied, they consider the CIT as an appropriate means for developing the conceptual structure for their research (Walker and Truly, 1992).

Critical incident technique helped to identify the topics that appear when accountants assess the problems of implementation of accounting standards.

\section{Survey to identify critical incidents}

To collect the necessary information are used surveys. For conducting interviews are engaged colleagues who are working in the profession of accounting and auditing, who interviewed accountants of entities, in order to obtain relevant answers about the questions in the form of interview.

In this connection interviewed 15 accountants of entities, who were asked to respond to an identical question:

\section{"Do you have problems in the application of accounting standards in your entity and what are they?"}

From interviews conducted in connection with this problem, made with accountants of interviewed entities, are collected a total of 85 cases of critical incidents (Table 1).

Table 1

\begin{tabular}{|l|l|l|l|}
\hline & Description & $\begin{array}{l}\text { Nr. of } \\
\text { incidents }\end{array}$ & $\%$ \\
\hline 1 & IAS / IFRS are voluminous & 12 & 14.12 \\
\hline 2 & Are IAS / IFRS are complicated & 11 & 12.94 \\
\hline 3 & Problems due to frequent changes of IAS / IFRS & 11 & 12.94 \\
\hline 4 & Inadequate translation & 10 & 11.76 \\
\hline 5 & Uncertainty & 9 & 10.59 \\
\hline 6 & Great divergence between IFRS and local tax lawS & 7 & 8.24 \\
\hline 7 & Management is not interested in implementation of IAS / IFRS & 7 & 8.24 \\
\hline 8 & The implementation of IAS / IFRS is costly & 6 & 7.06 \\
\hline 9 & Terminology & 6 & 7.06 \\
\hline 10 & Discrepancy & 4 & 4.71 \\
\hline 11 & Other & 2 & 2.35 \\
\hline & Total & 85 & 100.00 \\
\hline
\end{tabular}

The results presented in the table show that the International Accounting Standards are voluminous, which is observed in 12 cases and participates with $14.12 \%$ in the total critical incidents found by the interviews conducted. IFRS are complex and change often it is reported in 11 cases of critical incidents. Inadequate translation of IFRS is reported in 10 cases of critical incidents.

Other findings were reported in the number and percentage of their participation in total of critical incident techniques. 


\section{Hypotheses}

For the design of the hypotheses we are based in cases of critical incidents, obtained from interviews conducted with accountants of economic entities.

These hypotheses are as follows:

H1 = Problems in the practical application of IAS / IFRS in Kosovo are in their complexity and frequent changes.

H2 = Entities have inadequate attitude regarding the implementation of IFRS.

H3 = Small and medium entities must apply IFRS for SMEs.

\section{The research questionnaire}

The data obtained from interviews conducted by the method of critical incidents and previous findings from the review of relevant literature in this field, have served as a basis for the design of the research questionnaire.

To test the hypotheses, was designed research questionnaire, which enables the identification of problems faced by entities in the compilation of financial reports. The questionnaires were sent to the accountants of entities in the period JanuaryFebruary 2014. The questionnaires were sent via mail to 180 businesses, and 52 questionnaires were received and were judged useful for the study.

\section{Analysis, data explanations}

To test the hypothesis we have processed and analyzed the results of the data collected.

$\mathrm{H1}=$ Problems in the practical application of IAS / IFRS in Kosovo are in their complexity and frequent changes.

To test this hypothesis, we have analyzed the responses to our questionnaire regarding voluminous, complexity and frequent changes of IAS / IFRS (Tab. 2, 3 and 4).

\section{Table 2}

Are the IAS / IFRS voluminous?

\begin{tabular}{|ll|l|l|l|l|}
\hline & Frequency & Percent & Valid Percent & Cumulative Percent \\
\hline Valid & no & 8 & 15,4 & 15,4 & 15,4 \\
& n/a & 3 & 5,8 & 5,8 & 21,2 \\
& yes & 41 & 78,8 & 78,8 & 100,0 \\
Total & 52 & 100,0 & 100,0 & \\
\hline
\end{tabular}

\section{Table 3}

Are the IAS / IFRS complicated?

\begin{tabular}{|ll|l|l|l|l|}
\hline & Frequency & Percent & Valid Percent & Cumulative Percent \\
\hline Valid & no & 12 & 23,1 & 23,1 & 23,1 \\
& n/a & 2 & 3,8 & 3,8 & 26,9 \\
& yes & 38 & 73,1 & 73,1 & 100,0 \\
Total & 52 & 100,0 & 100,0 & \\
\hline
\end{tabular}




\section{Table 4}

Do you have problems due to frequent changes of IAS / IFRS?

\begin{tabular}{|ll|l|l|l|l|}
\hline & Frequency & Percent & Valid Percent & Cumulative Percent \\
\hline Valid & no & 9 & 17,3 & 17,3 & 17,3 \\
& n/a & 2 & 3,8 & 3,8 & 21,2 \\
yes & 41 & 78,8 & 78,8 & 100,0 \\
& Total & 52 & 100,0 & 100,0 & \\
\hline
\end{tabular}

From the above results of the paper can be concluded that the hypothesis $\mathrm{H} 1$ that has to do with the complexity of international accounting standards and their frequent changes, it is proven in its entirety, since over $70 \%$ of respondents think that the IAS / IFRS are voluminous, complex and change frequently.

\section{H2 = Entities have inadequate attitude regarding the implementation of IFRS.}

To test this hypothesis, we analyzed the answers to our questions regarding the disinterest of management for implementation of IAS / IFRS (Tab.5)

\section{Table 5}

Is management not interested in implementation of IAS / IFRS?

\begin{tabular}{|ll|l|l|l|l|}
\hline & Frequency & Percent & Valid Percent & Cumulative Percent \\
\hline Valid & no & 22 & 42,3 & 42,3 & 42,3 \\
& n.a & 1 & 1,9 & 1,9 & 44,2 \\
& yes & 29 & 55,8 & 55,8 & 100,0 \\
& Total & 52 & 100,0 & 100,0 & \\
\hline
\end{tabular}

As stated above, we conclude that the hypothesis $\mathrm{H} 2$ is proven, regarding management's disinterest for the implementation of IAS / IFRS, because $55.8 \%$ of respondents answered in favor.

\section{H3 = Small and medium entities must apply IFRS for SMEs.}

To test this hypothesis, we have analyzed the responses to our question: should SMEs to apply IFRS for SMEs? Results are presented in the following table:

\section{Table 6}

Should SMEs to apply IFRS for SMEs?

\begin{tabular}{|ll|l|l|l|l|}
\hline & Frequency & Percent & Valid Percent & Cumulative Percent \\
\hline Valid & no & 2 & 3,8 & 3,8 & 3,8 \\
& n/a & 2 & 3,8 & 3,8 & 7,7 \\
& yes & 48 & 92,3 & 92,3 & 100,0 \\
& & & & \\
& Total & 52 & 100,0 & 100,0 & \\
\hline
\end{tabular}


As was noted in the table above, we can conclude that the hypothesis $\mathrm{H} 3$ is proven, about the reasonability of implementing the IFRS for SMEs, for small and medium entities, because $92.3 \%$ of respondents answered in favor.

Our results are supported by findings of previous studies. MG Baldarelli, Demartini P., Skare ML (2007), have come to the conclusion that the application of IAS in Croatia entities has been low due to their complexity.

Pacter (2013), has found that SMEs, in case of application of IFRS for SMEs, freed from the burden of applying full IFRS.

Fitzpatrick and Frank (2009) state that SMEs are entities that publish general purpose financial statements for external users and do not have public accountability.

The accounting profession has long struggled with the idea that the financial reporting needs of small, closely held businesses often differ from those required by large, publicly traded companies (Zanzig, \& Flesher, 2006).

Standard setters have made their requirements deliberately difficult to implement (Moore, 2002).

\section{Conclusions / Recommendations}

Results of this study show that IAS / IFRS are complex and voluminous and their implementation requires certain knowledge by professionals. The current accounting law in Kosovo requires from SME to apply IAS / IFRS, which is completely irrational and illogical.

Most countries in the region and in the whole world in their legislations have regulated this thing so that for SMEs to apply IFRS for SMEs or have adopted national accounting standards for their needs.

Results of this study show that the majority of respondents believed that SMEs should apply IFRS for SMEs. This is reasonable since the IFRS for SMEs is adapted to small and medium enterprises that do not have public accountability, shares which are not traded in financial markets. This standard takes into account the capabilities of SMEs to prepare financial information and the cost of their preparation.

We recommend changes to the current Law on financial reporting in Kosovo, so that SMEs must applying IFRS for SMEs because this standard is suitable for these entities and enables comprehensive and transparent financial reporting.

In order to improve the situation regarding the implementation of IAS / IFRS recommend that professional associations to organize continuous trainings and professional staff participate in regular trainings with regard to these standards.

Results of this study show that the management of entities is not interested in the implementation of accounting standards. This fact is worrying and illogical in terms of the need for comprehensive and transparent financial reporting.

We recommend professional associations to organize meetings with the management of entities in order to make their awareness about the importance of the implementation of IAS / IFRS for financial reporting by watching the possibility of hiring professional accounting staff.

\section{References}

[1] Baldarelli M. G., Demartini P., Skare M.L. Application of accounting standards in small and medium enterprises in Italy and Croatia: challenges of international harmonization, (2007).

[2] Bohusova H., (2007), "The Possible Ways to IFRS (International Financial Reporting Standards) for Micro-Entities Development (an Investigation of usefulness).

[3] C.N. Albu, N. Albu, and S. Fekete, The context of the possible IFRS for SMEs implementation in Romania. An exploratory study, Accounting and Management Information Systems, Vol. 9, No.1, 2010, pp. 60-72.

[4] Ding Y., Hope O., Jeanjean T. and Stolowy H. (2007), "Differences between domestic accounting standards and IAS: Measurement, determinants and implications", Journal of Accounting and Public Policy, 26 (1), pp. 1-38. 
[5] Epstein, JB and Jermakowicz, KE 2010, WILEY Interpretation and Application of International Financial Reporting Standards 2010, New Jersey: John Wiley \& Sons.

[6] Gallhofer S., Haslam J., (2006), "The accounting- globalization interrelation: An overview with some reflections on the neglected dimension of emancipatory potentiality", Critical Perspectives on Accounting 17, pp. 903-934.

[7] HA van Wyk J., Rossouw, "IFRS for SMEs in South Africa: a giant leap for accounting, but too big for smaller entities in general Centre for Accounting Centre for Accounting University of the Free State (2009)".

[8] IASB, IFRS for Small and Medium-Sized Entities, London: IASB, 2009 latridis G., (2007) "Implementation of International Financial Reporting Standards and the Quality of Financial Statement Information; An Investigation of Earnings Management and Value Relevance", MIBES 2007, pp. 88-136.

[9] KKRF, Këshilli i Kosovës për Raportim financiar, Udhëzimi administrativ 2012/04

[10] Ligji 04/L-014, Ligji për Kontabilitet, raportim financiar dhe auditim (2011)

[11] Mc Gee, R., "Adopting and Implementing International Financial Reporting Standards in transition economies", International Accounting Standards, Regulations and Financial Reporting. Ed Greg Gregriou and Mohamed Gaber. Elsevier Ltd. 199-

[12] 221 (2006).

[13] M Sacer, S. R. Posavec: Analiza problema praktične primjene međunarodnih standarda finansijskog izvestavanja u Republici Hrvatskoj, Ekonomski pregled, 63 (9-10) 541-560 (2012)

[14] Pacter, P. The IFRS for SMEs, The Routledge Companion to Accounting, Reporting and Regulation (2013).

[15] R.K. Larson, and D.L. Street, "Convergence with IFRS in an expanding Europe: progress and obstacles identified by large accounting firms' survey", Journal of Accounting, Auditing and Taxation, Vol. 13, 2004, pp. 89-119.

[16] SHKÇAK, Departamenti i shërbimit për anëtar, Pse duhet aplikuar Standardi Ndërkombëtar i Raportimit Financiar për Ndërmarrjet e Vogla dhe të Mesme (IFRS for SME) në Kosovë? (2011)

[17] Thornton. G., International Financial reporting Standards and accounting change implementation services at a glance. Grant Thornton LLP (2012).

Zager, K., M. Sacer, I. "Usporedba MSFI vs. HSFI, prednosti i nedostaci, problemi primjene i usporedivost", U: Zbornik radova 43. Simpozija "Financije i računovodstvo u funkciji jačanja konkurentnosti hrvatskog gospodarstva", HZRFD, Pula, 5-7. lipnja2008., str. 96-109. (2008).

[18] Zeghal D. and Mhedhbi k., (2006), "An analysis of the factors affecting the adoption of international accounting standards by developing countries". 